\title{
THE MEANING BEHIND THROWING CHICKEN IN WEDDING CEREMONY Study of Kudus Kulon And Wetan Society
}

\author{
Muhammad Fadhlullah \\ Master Program, Sosciology of Religion, UKSW Salatiga \\ mfadhlullah@gmail.com
}

\begin{abstract}
Our living traditions are an inheritance from our ancestors. One of them is Chicken Throwing ritual in Kudus City. This tradition celebrated when a villager of Kudus Kulon get married with Kudus Wetan society or in contrary. A villager should throw a chicken in Gelis bridge to eliminate the bad effect from spirits in this bridge. Almost of old people in the past include meaning in every tradition, they give some message not directly but in symbols. So that's way the author want to describe what the meaning behind chicken throwing in wedding ceremony of Kudus society. This research used a qualitative method trough in depth interview to gain data. To analysis data, this research used the semiotic of Charles Sander Pierce. In sum, the tradition of Chicken Throwing has many meanings. Firstly, in Hindhu era this tradition was a symbol of offering that give to the spirits in Gelis river. Secondly in followers of Sunan Kudus era this tradition has the different meaning. They move to the purpose of this tradition became shodaqoh given to the vagrants. Thirdly, in this era it is carried out only on the basis of orders from parents or just hereditary.
\end{abstract}

Keywords: chichen, Kudus, wedding's ritual, Peirce's semiotic.

\section{A. Introduction}

A civilization can not be separated from the culture, like a pair of currencies. Before going any further, need to understand what is meant by culture. Culture is like a lens. Just imagine if you are wearing lenses to see through something then you will choose one particular focus, of that you will target object appropriately. ${ }^{1}$

The term of culture in etymologically is: customs, beliefs, art, way of life of particular country or group. ${ }^{2}$ According to Zoetmulder and Koentjaraningrat, Based on the root of the word buddhi, the term culture is within the scope of "matters concerned with the mind". ${ }^{3}$

Culture is a development of the word budi-daya, which means the power of mind such as: creativity, initiative, and sense. Culture is the result of creativity, initiative, and a sense of it. Thus, both Koentjaraningrat and Zoetmulder, putting culture to "something that is

\footnotetext{
${ }^{1}$ Alo Liliweri, Makna Budaya Dalam Komunikasi Antar Budaya, $17^{\text {th }}$ edition, (LKIS, Yogyakarta, 2003)

2 Oxford learner's Pocket Dictionary, 105.

${ }^{3}$ Mudjahirin Thohir, Memahami Kebudayaan Teori Metodologi dan Aplikasi, $1^{\text {st }}$ edition, (Fasindo Pers, Semarang, 2007), 18 .
} 
easy-going, has been formed " as a result if a sense, initiative, and a sense of human society. ${ }^{4}$

There are also other definitions. Like, culture is a way of life of a group of people in the form of the behavior, beliefs, values, and symbols -that they receive without conscious or without thinking- all of which are inherited through the process communicates and imitation from one generation to the next generation. ${ }^{5}$

Culture consists of patterns that explicitly or implicitly from and to a particular behavior that is routed through a symbol that is an achievement human group -shaped artifacts including relics that are the core or essence of the ideas of tradisioanal- and packed in value they have received. With other words, the culture system can be explained through the product or action which is seen to be a factor affect thei ractions. ${ }^{6}$

After seeing definitions above it can be concluded that culture is very important for human life. Thus the author will be reviewing the specifics of the culture in Kudus, Central Java is famous for the porridge and students. According to the author in that area a lot of culture that need to be assessed so as not to become just history in the pass .

According to the history, Kudus is city has strategic location, because it is an area pass that connects the surrounding areas. East region, such as Pati, Tayu, Juwana, Rembang, Lasem and Blora and west area is like Mayong, Jepara and Bangsri use Kudus as a connector that connects Semarang as administrative center of the province. In addition to its function as the connector, Kudus city including the bustling city, known as the sanctuary, is counted as an industrial town. There, we find a lot of cigarette industry, sugar, weaving, printing, and so forth. ${ }^{7}$

Because of the location and environment in which to trade, so the majority of Kudus people work as a traders. More specifically Kulon ${ }^{8}$ community. According to sources, there were Kulon people traders more than the Wetan'society. Previous researcher has to explain why there is Kudus Kulon and Wetan society.

In the city there is a Gelis river flowing to the south and divides the city into two parts, namely Kudus Wetan and Kulon. Kulon located in the west of the river and the Wetan located in the east side of the river. Kulon is also known as Kauman village. There are historical and archaeological heritages in Kauman which is quite well known that is the tower of the mosque and tomb of Sunan Kudus. This area during colonial rule is a fief area. In addition, there is a China village settlement in Kudus Kulon located in the area around Kudus market, not far from the sanctuary tower complex. In the Chinese village there is a temple which is considered the oldest in Kudus. Relic ancient history and other such

\footnotetext{
${ }^{4}$ Ibid.

5 Ibid., 8 .

${ }^{6}$ Ibid.

${ }^{7}$ Solichin Salam, Kudus Purbakala Dalam Perjuangan Islam, (Kudus: Menara Kudus ,1997), 1.

${ }^{8}$ Kulon is javannes word mean west

${ }^{9}$ Wetan is javannes word mean east
} 
dispersed mosque, stone Lumpang, Kyai Telingsing Grave, home pencu ${ }^{10}$ Kudus custom, boat houses and twin palace. ${ }^{11}$

Furthermore, in Kudus Wetan is central of government, local government and colonial government. In this area at the time of the Dutch, where people of European settlement China. Along the road from the square to the east towards majoring starch contained settlement of the Dutch. Chinese village located on the square arround among others in the Panjunan village, Keramat, Wergu Kulon and Anyar market. In Kudus Wetan also include historical and archaeological heritage, among others, the former sanctuary pavilion district railway station, the grand mosque Kudus city, Kawedanan pavilion, churches, and Rendeng sugar mills. ${ }^{12}$

The division of Kudus area into two part, give some problem at the time. History records that the progress of social aspect in Kudus achieved by the majority of the people Kudus Wetan from royalty and nobility. While Kudus Kulon people which at that time still strugling with trading word. Kudus Wetan despise Kudus Kulon people. World trade is considered not able to raise their social status.

This conflict continued until the People of Kudus Kulon advanced and more glorious than Kudus Wetan. As the shape of the progress realized by build custom home building. Residential houses made of wood choices and it is definitely not cost you a bit. Indirectly show that once looked down upon now could be above them. ${ }^{13}$

This situation influence wedding ritual between two communities. For them, a marriage is make two families into one. Therefore, marriage which unites the two parts of the holy eventually led to a unique culture that is procession of throwing chicken in Gelis river. Every people of Kudus Kulon who gets a mate Kudus Wetan should throw the chicken required in the river, and on the contrary. Here proof, that the economy can not be separated from the culture. Each economic development requires mind value or cultural values15.

Based on the explanation above, the researcher wants to capture about the meaning of chiken throwing as a local wedding's ritual by a semiotic approach of C.S Pierce. So, there are two questions to answer how a Chicken Throwing ritual committed by Kudus society is? What does the ritual means for Kudus people?

\section{B. Discussion}

\section{Ritual of Chicken Throwing in Wedding Ceremony}

Kudus has cultural and soial diversity. This condition makes Kudus colorful. Religious aspect harmony created very harmonious. Can be find that behind Menara Kudus complex there is klenteng which until now still awake and well-maintained.

\footnotetext{
${ }^{10}$ Pencu is javannes word mean home have coneroof

${ }^{11}$ Dinas Pariwisata dan Kebudayaan Kabupaten Kudus, Peninggalan Sejarah dan Purbakala Kabupaten Kudus, 8.

${ }^{12} \mathrm{Ibid}, 9$.

${ }^{13}$ Nur Said, Tradisi Pendidikan Karakter Dalam Keluarga Tafsir Sosial Rumah Adat Kudus, $1^{\text {st }}$ edition, (Kudus: Brilian Media Utama, 2011)
} 
Kudus culture is very interesting, one of them is ritual of chicken throwing, this tradition done when some couple bride are comes from Kudus Kulon and Wetan society. As the author explained about Kudus Kulon and Wetan. The divide between the two areas is Gelis river. ${ }^{14}$ According to the belief of local people river is a place or kingdom for the supernatural beings, believed to be often distracting if not given sesajen.

History of Kudus in the past is so interesting. Before entering islam in Kudus city, the majority of Kudus people are Hindhu. With the proof of Menara Kudus mosque is an a Pure before. The place called by Kudus in the past is the place that located in west of Gelis river. $^{15}$

Arround of Kudus in the past was a zoo. Still so much trees life in arround Kudus city. Because of faith of Hindhu about myth was a strong so thay way has influence to the tradition now. A tradition that done when the people of Kudus Kulon and Wetan get married and pass to the Gelis river. This tradition is called as the "buwak sengkolo" with throw the chicken in the river.

According to the faith of Hindhu in the past, Gelis river was a kingdom of spirits the matter was a big snake. The snake was asceticism in Rahtawu montain. To eliminate this plague that do not wanted by them so they throw the chicken as the peace to the spirits. ${ }^{16}$

There is a belief if in ancient times rivers were also inhabited by dangerous animals. Because at that time there is a permanent bridge as it is today. Then throw the chicken as a hoax so that groups of a bridal who will pass through the river was able to walk safely and free from the disorder.

The interpretation of "buwak sengkolo" in the tradition is very common indeed. Sengkolo or in this case defined as mean can happen in reality is real and not real. The danger could be from impaired spirits or from the animals that live in the river.

In the Kudus people trust also if every bride that brings sawan. Which have an impact on the smooth running of the event. With offerings of chicken that was expected all the wedding procession sets can run smoothly.

When islam began to enter into the Kudus city which was brought by Sunan Kudus Shaykh Ja'far Shodiq. The traditions inherited from their ancestors experienced a change in meaning. Offerings are dumped into the Gelis river is deflected to shodaqoh.

Sunan Kudus in the history of the spread of islam is known as a tolerant figure against the cultural heritage and traditions existing in the Hindhu. He did not directly eradicate exhausted all existing traditions but will deflect to the correct Islamic guidance. This was the one who made the Da'wah Sunan Kudus can be accepted by the local community. ${ }^{17}$

As an example of a ban on the slaughter of cows for the Kudus people. This is one of the strategies he used to propitiate the Hindhu religions. Because cows are animals that are sacred by the Hindhu. And this strategy has succeeded in making their sympathy and converted to islam. Such confidence is still guarded by the most Kudus society especially in

\footnotetext{
${ }^{14}$ According to the story called "Gelis" because when it comes the flood cannot be predicted because it so quickly and the loss or reflux ever so quickly in just a matter of hours. So in Java language called "Gelis"

${ }^{15}$ Interview with Mr. Sutiyono at 11th Desember 2014 at 15.30 WIB

${ }^{16}$ Interview with Mr. Sancaka Dwi Pani

${ }^{17}$ Interview with Mr. Sutiyono
} 
the environment of the Menara Kudus. And even then there is also the myth that develop if there is a violation it will get evil.

Back on the tradition of dumping chicken made Kudus society if groups of brides passing Gelis river. At the beginning of that tradition is the offerings that were sacrificed to the spirits by Sunan Kudus deflected to alms or shodaqoh. As set out above. On the banks of the river or Gelis is an abode for the scavenger or bum.

The same tradition the same procession but had different goals. Chicken is tossed into the river bank is a form of sharing to a fellow. People who live on the banks of the river rarely feel riding the chicken meat. Then the tradition by having their delicious taste can take is.

Without these traditions have to eliminate and not to violate the teachings of the Islamic religion is not wrong if the success of the spread of islam in the Kudus City did not escape the ingenuity he used in preaching. Suppose just at that time he was firmly in the tradition of their ancestral heritage is eradicating the Dawah he will get a rejection from the local community.

Long time before humans know the great religions, even since the early history of humanity, beliefs about the delicate creatures already exists. The creature in view of their various. There are can not be seen at all, nothing appearing on certain people through a spell or an amulet, and there is also a pervasive on something so anyone have a chance to see it. ${ }^{18}$

After the development of the tradition of having a variety of shifts.Starting from the history and the meaning of the tradition. In fact most of the Kudus Community do not know exactly from whom or when beginning the tradition. They just did a hereditary as taught by parents and their predecessors..

Kasmuji (67 years old), a villager of Demakan (Kudus Wetan), who lived on the banks of Gelis river said if the ritual of chicken throwing already exist at the time of their ancestors. We as a generation only run what has already become a tradition that exists. We believe that every newlywed couwples bring "sawan" so with these exile chicken tradition can be eliminate and prevent newlywed from danger and doom. ${ }^{19}$

Kasmuji is also one of the people who ever get chicken in that ritual. He said: "I have got chicken from that tradition. You agree or disagree does not matter. The chicken from this tradition is easy to keep. I have ever had 50 chickens from this tradition".

No one knows about the history when the tradition began. Almost every citizen that the author encountered say the same.

Mr. Totok Demangan resident (54 years old) (Kudus Kulon) explained that it had already existed from old time. He said: "if you ask to me when the tradition begine $i$ do not know, because this tradition was begine in the past, i just continue what the people done. Oldest has belief river is place of spirits kingdom. Make bridal free from spirit annoyance".

The belief made the hereditary tradition such as mandatory is implemented. Suggestion will get bad or evil impact many believed local societies. But it is also been said

\footnotetext{
${ }^{18}$ M. Quraish Shihab, Jin, Iblis, Setan dan Malaikat Yang Terrsembunyi, $1^{\text {st }}$ edition (Lentera Hati, Jakarta, 2002), 15.

${ }^{19}$ Interview with Mr.Kasmuji in his home at Demakan village 15th September 2014 at 10.00 WIB
} 
if that becomes their respective beliefs. If sure there are effects, then if not implemented later will get the plague. ${ }^{20}$

But, there are people do not belief for this tradition. Among urban or modern circlesas well as many who didn't do the tradition. One of the factors underlying disease is the lack of penagjaran of the elderly and the weakening confidence in the traditions of their ancestral heritage. That makes them increasingly steady is not the occurrence of impact as told by many people. If there's someone who breaks the tradition they will get the hazards, such as collision, illness or divorce.

Talking about chicken Throwing ritual procession, it executed when the groom is about to do a covenant of marriage at the residence of the prospective bride. The cortege will pass through the bridge and then disposing of the chickens brought from home on the edge of the bridge. Like the one in the picture below.

This is called by local people as a tradition "buwak sengkolo" which means throwing away the plague. This type of chicken is used up than have events. If the economy is strong can wear a rooster or chicken that is already up, whereas if the intention economy only got the chicken could be smaller. Most importantly their chickens must alive. ${ }^{21}$

In ancient times the motorcade of the bridegroom's men follow by horse or wagon decorated beautifully. The horse was a dashing and nice selected. Wagon and horses used to be decorated with ornaments "kembang mayang". Decoration indicates if the motorcade it was groups of bride and groom. Community under the bridge, ancient or commonly referred to "kere ngisor jembatan" will go to the bridal party in droves to snatch a chicken will be discarded.

Any effect on the economic level total and good wagon and horses used. The rich have the event, the more great wagon and worn. H. Selamet said: "Wagon use in wedding ceremony depend on economic of bridal family. If from richman wagon is beautiful. If from common people there is no special".

Examples of cases of marriage Kudus Kulon and Wetan the marriage Muhammad Zain Nur (30), a son of Mr. H. Muzammil, from the village of Demakan (Kudus Wetan) with Afrihana Nur (25), a daughter of Mr. H. M. Rashid, from the village of Kajeksan (Kudus Kulon). ${ }^{22}$

Akad nikah held on August 23, 2014 in Kajeksan village. Such traditions existing before crossing the gelis river bridge family of candidate of groom throwing the chickens on the edge of the bridge. However, the difference is that the motorcade are used instead of the wagon but cars and motorcycle. The family assumed importance already dispose of chicken as a condition. If using cars are easier and simple. ${ }^{23}$

The people believe that onyone who ignores this ritual will get a bad luck. A suggestion has already formed in the subconscious of the Kudus Kulon and Wetan society if they not implementing these traditions or rituals, they will get the plague.

\footnotetext{
${ }^{20}$ Interview with Mr. Totok (the keys of Masjid bubar) 17th September 2014 at 18.30 WIB

${ }^{21}$ Interview with H.Selamet (79) in Langgar Dalem Village 15th September 2014 Village 15th September 2014 at $13.30 \mathrm{WIB}$

${ }^{22}$ Interview with Mrs. Hj. Zuriyah in Demakan village 15th September 2014 at 09.00 WIB .

${ }^{23}$ Interview with Mr. Syafi'i in Demakan village 15th September 2014 at 11.00 WIB .
} 
The impact of the offence this may cause usually overwrite to his bride. There is a real story hit the bride who forgot to carry out the tradition. The bride suddenly got hysterical and cannot be controlled or in the Kudus people called by ngromyang. Of the immediate family brought the incident to the dukun. After analysis, he said that the who forgotten bride do the tradition of dumping chicken in bridge Gelis river. ${ }^{24}$

Upon returning from the shaman, the bride's family directly implement the suggestions of the shaman. By bringing a big cock, the family went to the bridge and orders Gelis river someone who was there to witness that they have conducted the ceremony. Amazing the bride that ngromyang is instantly healed. ${ }^{25}$

\section{The Chicken Throwing as A Syimbol}

Peirce said that if a sign is something which represents something. Every sign has its own. Dependent interpret or ideology that developed in the surrounding communities. In Peirce's thought to mention that sign if seen from the object is divided into three parts:

a) Icon is a sign that the relationship between signified and signifier are simultaneously natural forms. Or in other words, the icon is the relationship between the sign and the object or reference that is both similarities: for example, portraits and map.

b) Index is the sign that shows that there is a natural relationship between signs and signifier that are causal relationships or causal, or sign which directly refers to the fact. The most obvious example is the smoke as a sign of the presence fire.

c) Symbol is sign indicating a natural relationship between the signifier with petandanya. The relationship among them are arbitrer or semena, relationships based on conventions (pledge) society. ${ }^{26}$

Peirce explained if symbol is the sign indicating a natural relationship between the signifier with petandanya. The relationship among them are arbitrer or semena, relationships based on conventions (pledge) society. ${ }^{27}$

Judging from the time and space that existed at the time there are some traditions that are traversed by the tradition of dumping chicken. The first is the beginning of the tradition in the Hindhu. During this period almost all existing ritual is based on the belief of animism. Offerings devoted to fine spirits in order to find salvation.

The second is when the came brought by Sunan Kudus followers. This is where the start is no changes brought by him against the local traditions that exist. Islamic values are inserted into an existing tradition without altering the external packaging.

In this case the author also look at the tradition of dumping chicken as a symbol depicting the meaning contained in the symbol. Viewed from various aspects of the object granted to the tradition symbol turned out to provide a variety of meanings and interpretations.

\footnotetext{
${ }^{24}$ Interview with Mr.Totok

${ }^{25}$ Interview with Mr.Totok

${ }^{26}$ Alex Sobur, Semiotika Komunikasi, (Bandung: Remaja Rosdakarya, 2006)

27 Ibid.
} 
The first authors will see the traditions at the beginning-that is, as a tradition belonging to the Hindhu. Hindhu society tradition in the belief this was done as an offering to the spirits that reside in the river Gelis. They believed if the spirits are there on the river that would be disruptive and cause bad impact for prospective pegantin.

It is seen from the history of the tradition was originally very creamy with the myth. Animism that is rooted in the mayarakat mindset in ancient times larger to things that do not seem rather than things that look.

According to the beliefs of the people in ancient times Hindhu Gelis River is a living creature that takes the form of a snake. The Snake is a snake that is being seokar lived as a hermit on Mount Rahtawu. To avoid unwanted hazard by them then dibuanglah the chicken was as delicate beings peace to it.

There is a belief if in ancient times rivers were also inhabited by dangerous animals. Because at that time there has not been a permanent bridge as it is today. Then throw cock as a hoax so that groups of bridal who will pass through the River was able to walk safely and free from the disorder.

Peirce's theory of signs about the destination object in the tradition of the delicate creatures that exist on the river. So the tradition is the symbol of offerings provided as a way to resist the dangers that exist. In this case the tradition of dumping chicken is seen as a symbol of offerings or reject timber.

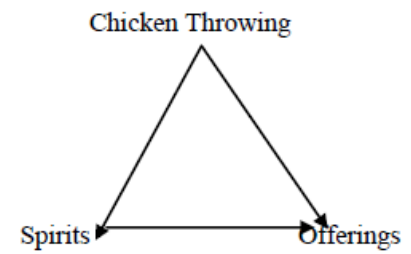

Reject timber is indeed one of the biggest factors that underlie sato from many traditions developed in the community along with the sacred in General. Almost every activity is believed to have had timber or misfortune. This is an already entrenched customs and is believed to be hereditary without need of evidence or proof.

After the coming of islam to the Kudus City by Sunan Kudus the tradition underwent a shift in meaning, however, tradition and prosesinya remains the same. Disposal of chicken is done by groups of brides who passed the Hindhu Gelis River is as a ritual of giving offerings to the spirits by Sunan Kudus changed its purpose.

View of the River at that time inhabited by bums and beggars and Sunan Kudus to the spirit of the original purpose of da'wah replacing the tradition of tết is a charity or to a fellow shodaqoh more needy. Share it to others as a form of social. Indeed historically have been mentioned if in ancient times many suburb inhabited by the homeless because of their limitations and so could not make a decent home.

The shift of meaning created by Sunan Kudus indeed described how his Da'wah strategies in spreading islam is very lenient with local culture. By changing the object from the tradition that was originally addressed to the spirits were replaced to the homeless and beggars.

So in this case the tradition role as $(\mathrm{R})$ associated with the object $(\mathrm{O})$ bums have given new meaning as a charity event or shodaqoh. There is a meaning shift as a Da'wah 
strategies of Sunan Kudus. Then, (I) are produced as a strategy is Shodaqoh Da'wah. In Peirce's thought to mention that sign if seen from the object is divided into three parts:

a) Icon is a sign that the relationship between signified and signifier are simultaneously natural forms. Or in other words, the icon is the relationship between the sign and the object or reference that is both similarities: for example, portraits and map.

b) Index is the sign that shows that there is a natural relationship between signs and signifier that are causal

relationships or causal, or sign which directly refers to the fact. The most obvious example is the smoke as a sign of the presence fire.

c) Symbol is sign indicating a natural relationship between the signifier with petandanya. The relationship among them are arbitrer or semena, relationships based on conventions (pledge) society. ${ }^{28}$

Kasmuji (67) villager of Demakan (Kudus Wetan), who lived on the banks of the Gelis river said if the ritual of chicken throwing already exist at the time of their ancestors. We as a generation only run what has already become a tradition that exists. We believe that every newlywed couwples bring "sawan" so with these exile chicken tradition can be eliminate and prevent newlywed from danger and doom. ${ }^{29}$

The history when tradition iti began no one knows. Almost every citizen that the author encountered say the same. Mr. Totok Demangan resident (54) (Kudus Kulon) explained as if from a young tradition that already exists.

The belief made the hereditary tradition such as mandatory is implemented. Suggestion will get bad or evil impact many believed local societies. But it is also been said if that becomes their respective beliefs. If sure there are effects, then if not implemented later will get the plague. ${ }^{30}$

But, there are people do not belief for this tradition. There are part of Kudus people does not believe wtih that tradition. For example is from Muhammadiyah people, they are give argument this tradition is form of ishraf or spend our wealth and is mentioned as offerings. Because give offering to spirits in Gelis river.

One of the teachings given by sunan Kudus was continued by the next generations. Although they have been converted from the original non-religious islam then became Muslims.

In today era, the tradition of dumping chicken in river Gelis merely hereditary tradition of being taught by their parents. Their parents teach if there are any groups of brides who will pass through the river Gelis required throw chickens.

Those who now do not know the history of tradition and the tradition of the holding of destination. They just menyakini if what is being taught by their predecessor there was intent and purpose. And their menyakini if not running the tradition will get the plague.

Kudus Kulon and Wetan on nowadays see the traditions of their ancestral heritage that should be preserved. Symbol dumping chicken traditions associated with their

\footnotetext{
28 Ibid.

${ }^{29}$ Interview with Mr.Kasmuji in his home at Demakan village 15th September 2014 at 10.00 WIB

${ }^{30}$ Interview with Mr. Totok (the keys of Masjid bubar) 17th September 2014 at 18.30 WIB
} 
ancestors made the meaning will respect and adherence to the cultural heritage of their ancestors.

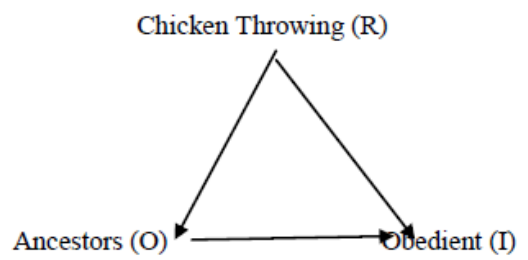

\section{The Meaning of A Chicken Throwing Ritual}

This rite has an evolving meaning from society. It's meaning always reconstructed by people of Kudus based on the values adhering to them. The meanings of achicken throwing ritual as follows:

\section{a. Early Period}

This tradition has existed in the 15th century before the Hindhu. Almost all the towns around Kudus did this tradition. As an example of Jepara, Demak, Pati. In the past every bride's entourage who will pass through the great river are required to throw the chicken in the river. According to their beliefs is the residence of Jin and spirits. To avoid distractions and dangers that exist then throw it as a symbol of waste chicken plague.

The great river became an important point needs to be emphasized in the tradition. Gelis times e.g., during approximately the $14 \mathrm{th} / 15 \mathrm{M}$ of century this holy river, which divides the public transportation for the trade sector. The river is famous for its fast. As the name "Gelis" comes from the Javanese language which means quick. There is another belief if in ancient times rivers were also inhabited by wild animals. As an example of the crocodiles, snakes and others. Because there will be groups of brides who will pass through the bridge so safe from the dangers of the beast dibungalah the chicken as a distraction.

The discarded chicken is a chicken alive, it can gain time for the bridal party to pass the river. Because it is still alive and needs to be more effort for the crocodile to chase the chicken.

In general the definition of dumping chicken tradition in those days, still the same from the area around the Kudus with Kudus themselves. That tradition was interpreted as a ritual disposal of the catastrophe, could be from spirits or dangers from wild animals at the great river dwellers.

b. Medieval Period

The second period was the follower of Sunan Kudus about 19th century a.d. at this time this tradition has already shifted its meaning. This tradition is meant as a tradition of charity to others. Chicken dumped addressed to people living Inn beside the river Gelis.

The definition given to followers of Sunan Kudus saw the reality that exists around them. At that time around the edge of the river is already the tramp or group of soial living River it. 
Then the chicken is removed that is not referred to as shirk and its meaning changed as "shodaqoh". In their view shodaqoh also aimed as balak. This is almost the same as in the previous period, which aims to resist evil.

c. Modern Period

The third period is on time today. On this tradition perode disposal of chickens had had no meaning. This tradition is carried out only on the basis of orders from parents or just hereditary. They believe if the tradition is inherited from their ancestors that should be preserved, if not do it then it will be hit by the plague.

There is also the tradition of not doing so because of different beliefs. There are menyakini if the tradition as a tradition of shirk and scatter delights. Like among nationalist and muhammadiyah.

\section{Conclusion}

From this discussion, it can be concluded that a chicken throwing ritual is some tradition that conduct if there is some people from Kudus Kulon or Wetan marriage each other. This tradition believed can eliminate and prevent newlywed from danger and doom. Entourage of bridal pass in Gelis bridge and throw chicken before they finish in they journey in the bridge. Tradition of Chicken Throwing has many meanings. First is, in Hindhu era this tradition is a symbol of offering that give to the spirits in Gelis river. Second, is in followers of Sunan Kudus era this tradition has the different meaning. They move to the purpose of this tradition became shodaqoh that given to the vagrants. Third is in this era is carried out only on the basis of orders from parents or just hereditary. 


\section{Bibliography}

Chappell, Ben, Folklore Semiotic: Charles Peirce and the Experience of Signs, PDF file.

Cobley, Paul, Routledge companion to semiotics and linguistics, London: Library of Congress Cataloging in Publication Data..

Liliweri, Alo, Makna Budaya Dalam Komunikasi Antar Budaya, $17^{\text {th }}$ edition, LKIS, Yogyakarta, 2003.

Said, Nur, Tradisi Pendidikan Karakter Dalam Keluarga Tafsir Sosial Rumah Adat Kudus, $1^{\text {st }}$ edition, Kudus: Brilian Media Utama, 2011.

Salam, Solichin, Kudus Purbakala Dalam Perjuangan Islam, Kudus: Menara Kudus ,1997.

Sanders Peirce, Charles, The Collected Papers of Charles Sander Peirce. Electronic edition reproducing vols. 1-6 [Hartshorne, C.; Weiss, P. (eds.), Cambridge: Harvard University Press, 1931-1935]; vols. 7-8 [Burks, A. W. (ed.), Cambridge: Harvard University Press, 1958].

Shihab, M. Quraish, Jin, Iblis, Setan dan Malaikat Yang Terrsembunyi, $1^{\text {st }}$ edition, Lentera Hati, Jakarta, 2002.

Sobur, Alex, Semiotika Komunikasi, Bandung: Remaja Rosdakarya, 2006.

Thohir, Mudjahirin, Memahami Kebudayaan Teori Metodologi dan Aplikasi, $1^{\text {st }}$ edition, Fasindo Pers, Semarang, 2007.

Interview:

Mr. Totok (the keys of Masjid bubar) 17th September 2014 at 18.30 WIB.

H.Selamet in Langgar Dalem Village 15th September 2014 Village at 13.30 WIB.

Mr. Syafi'i in Demakan village 15th September 2014 at 11.00 WIB.

Mr. Jumaidi in Janggalan village 15th September 2014 at 20.30 WIB.

Mr. Islahudin in Sunggingan village 15th September 2014 at 19.00 WIB.

Drs. Sutiyono, M.Pd 11th Desember 2014 at 15.00 WIB 